\title{
VIÊM ĐA SỤN TÁl DIẼN: BÁO CÁO HAI TRƯỜNG HỢP LÂM SÀNG
}

\author{
Trần Thu Giang ${ }^{1,2, \bowtie}$, Nguyễn Thị Thoa ${ }^{2}$, Phạm Thu Hằng ${ }^{2}$ \\ Đỗ Thị Huyền Trang ${ }^{2}$, Phạm Văn Tú ${ }^{2}$, Phạm Hoài Thu ${ }^{1,2}$
}

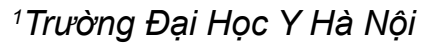

${ }^{2}$ Bệnh viện Đại học Y Hà Nội

Viêm đa sụn tái diễn (Relapsing Polychondritis - RP) là bệnh lý tự miễn gây tổn thương cấu trúc sụn và nhiều cơ quan, để lại di chứng nếu không được chẩn đoán và điều trị. Tuy nhiên đây là bệnh hiếm gặp, triệu chứng khởi phát có thể không điển hình, do đó khó chẩn đoán ở giai đoạn đầu. Mục tiêu của nghiên cứu là mô tả hai trường hợp viêm đa sụn tái diễn, nêu các đặc điểm chẩn đoán, giúp hướng tới chẩn đoán sớm bệnh, trình bày một số phương pháp điều trị bệnh. Phương pháp nghiên cứu mô tả chùm ca bệnh viêm đa sụn tái diễn điều trị tại Bệnh viện Đại Học Y Hà Nội. Kết quả nghiên cứu cho thấy hai bệnh nhân này đều có triệu chứng khởi phát là viêm sụn vành tai và sụn mũi chưa được chẩn đoán, sau đó xuất hiện thêm các triệu chứng như sốt, viêm khớp và được nhập viện. Hai trường hợp này đủ tiêu chuẩn chẩn đoán theo tiêu chuẩn McAdam năm 1976 và đáp ứng với điều trị. Kết luận: chẩn đoán sớm và điều trị viêm đa sụn tái diễn bằng thuốc chống viêm và ức chế miễn dịch đóng vai trò quan trọng để dự phòng biến chứng của bệnh.

Từ khóa: Viêm đa sụn tái diễn, bệnh tụ̣ miễn, relapsing polychondritis.

\section{I. ĐẠT VẤN ĐỀ}

Viêm đa sụn tái diễn (RP) đặc trưng bởi tình trạng viêm các cấu trúc sụn và các mô giàu proteoglycan khác trong cơ thể. Các cơ quan thường bị tổn thương bao gồm tai, mũi, mắt, khớp, đường hô hấp. Đây là một bệnh hiếm gặp, có tỷ lệ mắc ước tính là $3,5 / 1.000 .000$ dân/năm. Tuổi thường gặp từ 40 tới 50 tuổi. ${ }^{1}$ Bệnh biểu hiện từng đợt với triệu chứng lâm sàng đa dạng, không đặc hiệu dẫn tới việc chẩn đoán và điều trị chậm trễ gây di chứng hủy sụn, nặng nhất có thể dẫn tới nhuyễn, chít hẹp đường thở, biến dạng khớp, viêm mạch, tổn thương van tim không hồi phục. ${ }^{2}$ Thời gian trung bình từ khi khởi phát tới khi được chẩn đoán là 2,9 năm. ${ }^{3}$ Bệnh được mô tả lần đầu vào năm 1923 bởi Jaksch-Wartenhorst trên trường hợp bệnh nhân 32 tuổi có viêm đa khớp

Tác giả liên hệ: Trần Thu Giang

Trường Đại học Y Hà Nội

Email: ttrthugiang@gmail.com

Ngày nhận: 28/09/2021

Ngày được chấp nhận: 15/10/2021 không đối xứng kèm theo sưng đau tai ngoài. ${ }^{4}$ Sau đó, đã có thêm các báo cáo trường hợp bệnh có tổn thương tai, mũi, đường hô hấp điển hình (Estes, 1983; Krzysztof Pol, 2009; Ernst 2009);:5-7 trường hợp có tổn thương gan (Maria da Graça Ferronato, 2011) hay bệnh đi kèm với bệnh lý ác tính (Sahla, 2016). ${ }^{8}$ Ca lâm sàng đầu tiên ở Việt Nam trên bệnh nhân có tổn thương sụn vành tai và phế quản được mô tả năm 2004 bởi tác giả Lê Thượng Vũ. ${ }^{9}$ Các báo cáo đều cho thấy viêm đa sụn tái diễn là một bệnh có biểu hiện lâm sàng đa dạng, không điển hình và khó chẩn đoán, đặc biệt ở giai đoạn sớm. Do đó, trong bài báo này, chúng tôi xin báo cáo hai trường hợp viêm đa sụn tái diễn tại Bệnh viện Đại học $Y$ Hà Nội, trong đó có một bệnh nhân có tiền sử lao phổi khiến cho chẩn đoán và điều trị gặp nhiều khó khăn.

\section{BÁO CÁO CA LÂM SÀNG}

\section{Trường hợp thứ nhất}

Bệnh nhân nữ 58 tuổi nhập viện vì sốt, đau 
ngực. Năm tháng trước bệnh nhân bi sưng vành tai và vào viện được chẩn đoán viêm tai giữa rồi điều trị kháng sinh, ngoài ra bệnh nhân có kèm theo sưng, đỏ, đau ở sống mũi tự khỏi sau 10 ngày. Trước khi vào viện 4 tháng, bệnh nhân xuất hiện đau nhức, đỏ mắt 2 bên và được chẩn đoán là viêm kết mạc mắt, điều trị kháng sinh tra mắt Tobamicin và rửa mắt hàng ngày với nước muối sinh lý, bệnh có đỡ nhưng triệu chứng tái phát nhiều đợt. Trước khi vào viện 1 tháng bệnh nhân lại sưng nóng đỏ vành tai hai bên, đau thành ngực, gày sút 3 cân/ 1 tháng, sốt $38,5^{\circ} \mathrm{C}$. Khám lâm sàng sưng nóng đỏ đau sụn vành tai 2 bên, không tổn thương dái tai, không ù tai. Ân đau vị trí sụn sườn thành ngực

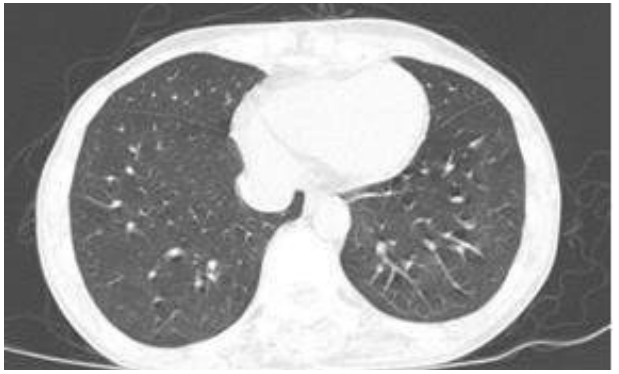

A: Phim chụp cắt lớp vi tính phổi hai bên, VAS 6-7 điểm. Gan to $2 \mathrm{~cm}$ dưới bờ sườn, ấn đau nhẹ. Viêm kết mạc mắt 2 bên, thị lực mắt phải $4 / 10$, mắt trái $5 / 10$.

Các xét nghiệm: chỉ số viêm: máu lắng tăng (113 mm sau $1 \mathrm{~h}, 118$ mm sau $2 \mathrm{~h}$ ). CRP tăng (14,39 mg/dL). Bạch cầu tăng (15.25 G/L), bạch cầu đa nhân trung tính $87,8 \%$. Thiếu máu hồng cầu nhỏ, nhược sắc $(\mathrm{Hb} 79 \mathrm{~g} / \mathrm{L}, \mathrm{MCV} 79,2 \mathrm{fL}$, $\mathrm{MCH} 25 p g, \mathrm{MCHC} 314 \mathrm{~g} / \mathrm{L})$. Tổng phân tích nước tiểu: protein niệu $1 \mathrm{~g} / \mathrm{L}$, hồng cầu 200 tế bào/uL. Anti-ANA, Ds-DNA: âm tính.

CT scan lồng ngực: hình ảnh vài dải xơ rải rác phân thùy 4-5 phổi 2 bên.

CT ổ bụng: gan to, theo dõi viêm bao gan.

Chẩn đoán: Viêm đa sụn tái diễn.

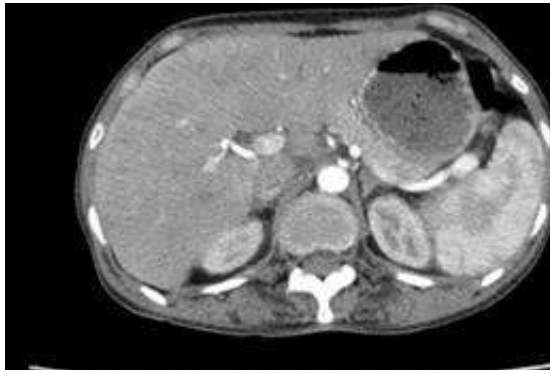

\section{B: Phim chụp cắt lớp vi tính bụng}

Hình 1. Hình ảnh phim cắt lớp của bệnh nhân

(Nguồn: bệnh nhân Đào Thị H. - 58 tuổi mã hồ sơ 2003000660)

\section{Điều trị}

Methylprednisolon (Medrol) 16mg x 2 viên/ ngày. Levocetirizine (Xyzal) $5 \mathrm{mg} x 1$ viên/ngày. Clobetasone (Eumovate): bôi vành tai ngày 3 lần, sáng - trưa - tối. Ofloxacin (Oflovid): tra mắt ngày 3 lần, cách 8h. Fluorometholone (Flumetholon) $0,1 \%$ : tra mắt ngày 2 lần, cách $12 \mathrm{~h}$.

Sau 7 ngày điều trị với phác đồ trên, bệnh nhân hết sốt, ăn tốt, sụn vành tai 2 bên đỡ sưng nóng, đỏ, đau; kết mạc mắt 2 bên không đỏ; đỡ đau thành ngực 2 bên, VAS 2-3 điểm; bụng mềm, gan mấp mé bờ sườn. Sau 3 tuần điều trị: các triệu chứng và xét nghiệm của bệnh nhân cải thiện rõ rệt. Bệnh nhân không sốt; không đau ngực; vành tai 2 bên không sưng, đau; kết mạc mắt không đỏ, thị lực mắt phải $6 / 10$, thị lực mắt trái $9 / 10$. Chỉ số viêm giảm, $\operatorname{CRP} 0,28 \mathrm{mg} /$ dL, máu lắng 38/67 mm. Siêu âm ổ bụng bình thường, gan không to. 


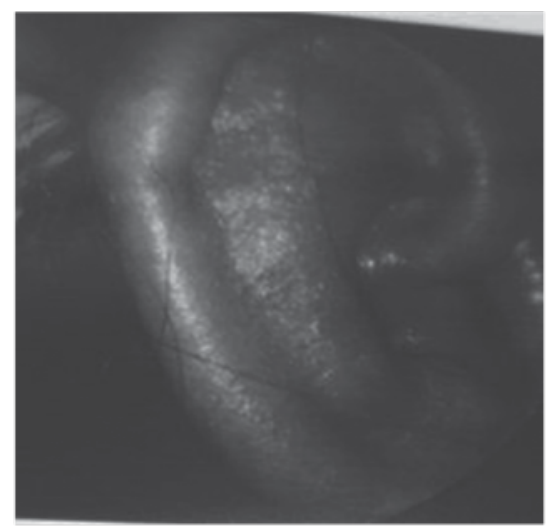

A.Hình ảnh viêm sụn vành tai trước điều trị

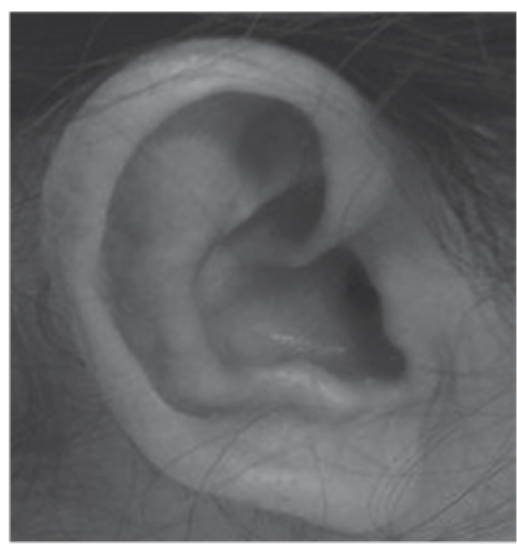

B.Hình ảnh sụn vành tai của bệnh nhân sau điều trị 3 tuần

Hình 2. Hình ảnh viêm sụn tai

(Nguồn: bệnh nhân Đào Thị H. - 58 tuổi)

\section{Trường hợp thứ hai}

Bệnh nhân nữ 34 tuổi tiền sử nhiều đợt sưng nóng đỏ sụn vành tai, sụn cánh mũi cách 2 năm. Một năm nay sưng đau khớp gối nhiều đợt. Cách đây 10 tháng bệnh nhân nổi hạch cổ trái được chẩn đoán lao hạch với mô bệnh học tổn thương lao và nuôi cấy lao dương tính. Bốn tháng trước bệnh nhân khó thở, nội soi phế quản hẹp gần như hoàn toàn buồng Morgani chẩn đoán lao thanh quản chỉ định mở khí quản và điều trị Isoniazid $0,3 \mathrm{~g} / \mathrm{ngày}$, Levofloxacin 0,8 g/ngày, Rifampicin 0,45 mg/ngày.
Một tháng trước vào viện bệnh nhân sưng đau nhiều khớp gối 2 bên, khớp cổ chân trái, 2 tuần trước vào viện bệnh nhân xuất hiện sốt, nhiệt độ cao nhất 39 độ.

Khám lâm sàng: Biến dạng vành tai hình súp lơ, biến dạng sống mũi hình yên ngựa. Mắt phải viêm thượng củng mạc thoái triển. Sưng nóng đau khớp gối 2 bên, khớp cổ chân trái. Phổi không ran.
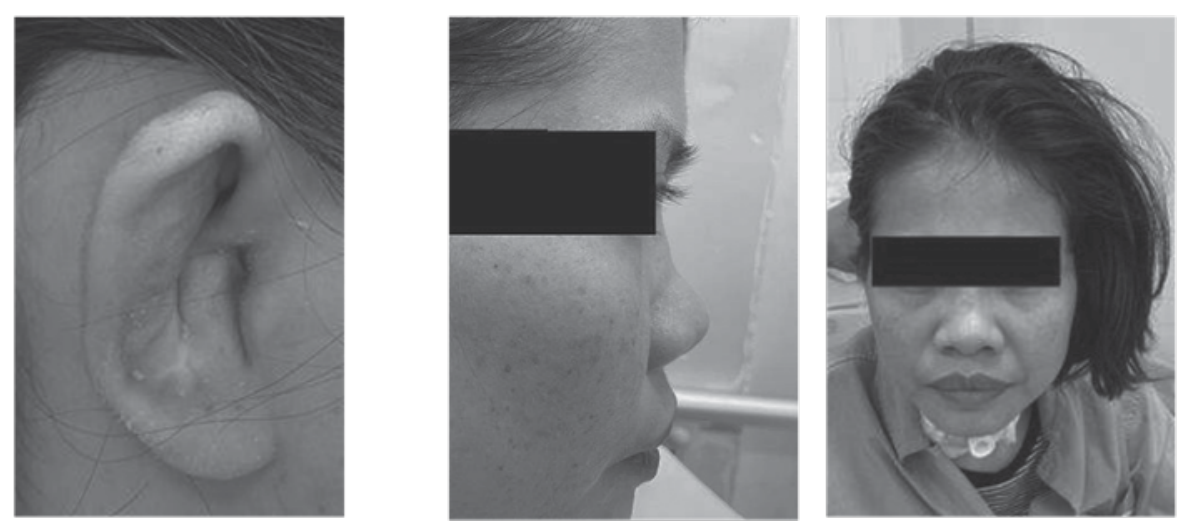

\section{A. Biến dạng vành tai hình súp lơ \\ B. Biến dạng sống mũi hình yên ngựa}

Hình 3. Hình ảnh tổn thương sụn vành tai và sống mũi

(Nguồn: bệnh nhân Trần Thị T. - 33 tuổi) 
Xét nghiệm máu: Hemoglobin $88 \mathrm{~g} / \mathrm{l}, \mathrm{MCV}$ $80 \mathrm{fL}, \mathrm{MCHC}: 283 \mathrm{~g} / \mathrm{l}$. Huyết đồ: thiếu máu nhược sắc - tủy tăng sinh (nghĩ do phản ứng). Máu lắng 108mm/115mm, CRP 7,17 mg/dL. HLA B27, RF, antiCCP âm tính, ANA 0,9 (âm tính), DsDNA 38,8 U/mL (dương tính). Dịch khớp: dịch viêm cấp, nuôi cấy vi khuẩn và $\mathrm{PCR}$ lao âm tính.

Nội soi tai mũi họng: viêm phù nề hạ thanh môn chưa loại trừ sẹo hẹp hạ thanh môn.

Giải phẫu bệnh sụn vành tai: (Tháng 6/2020 - Bệnh viện Phổi Trung ương): mô sụn

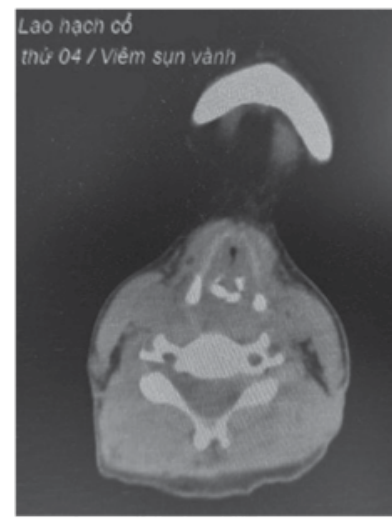

\section{A. Hẹp đoạn đầu khí quản}

và mô liên kết xơ xâm nhập bạch cầu trung tính, tế bào viêm và đại thực bào. Kết luận: vùng mô sụn viêm mạn tính. Cắt lớp vi tính lồng ngực lớp mỏng (22/10/2020- bệnh viện phổi trung ương): hẹp đọan đầu khí quản ngay dưới dây thanh âm hai bên, vị trí hẹp nhất 1-2 mm kéo dài khoảng $10 \mathrm{~mm}$, không thấy hình ảnh chèn ép hay dị vật bít tắc. Nội soi phế quản (21/10/2020 - Bệnh viện Phổi Trung ương): phù nề niêm mạc kèm ít hoại tử gây hẹp gần hoàn toàn buồng morgani.

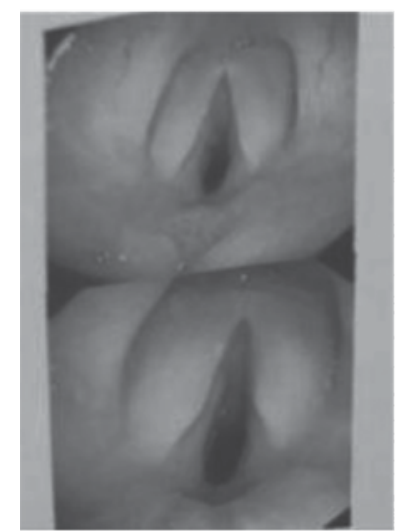

B. Phù nề, hẹp thanh khí quản

Hình 4. Hình ảnh phim chụp cắt lớp vi tính ngực và nội soi phế quản (Nguồn: bệnh nhân Trần Thị T. - 33 tuổi - mã hồ sơ 2104262663)

Chẩn đoán: Viêm đa sụn tái diễn/ lao hạch đang điều trị tháng thứ 9 .

\section{Điều trị}

Bệnh nhân được điều trị bằng Meloxicam (Mobic) $15 \mathrm{mg} /$ ngày trong 2 ngày nhưng các triệu chứng không cải thiện, bệnh nhân được dừng thuốc và chuyển điều trị với $40 \mathrm{mg}$ Methylprednisolon (Solumedrol), sau 10 ngày bệnh nhân hết sốt, nhưng vẫn còn sưng đau

\section{BÀN LUẦN}

Viêm đa sụn tái diễn là một bệnh lý tự miễn hiếm gặp gây tổn thương mô sụn và các mô giàu proteoglycan trong cơ thể. Nguyên nhân khớp gối, khớp cổ chân nhiều, VAS 8/10. Bệnh nhân được tăng liều Methylprednisolon lên 80 $\mathrm{mg} / \mathrm{ngày}$ kết hợp với methotrexate $10 \mathrm{mg} / \mathrm{tuần}$. Natri hyaluronate (Vismed): tra mắt ngày 4 lần, cách $6 \mathrm{~h}$. Fluorometholone (Flumetholon) 0,1\%: tra mắt ngày 2 lần, cách $12 \mathrm{~h}$. Bệnh nhân đỡ sưng đau khớp. Chỉ số viêm giảm, CRP 4,2 mg/ $\mathrm{dL}$. Duy trì thuốc lao theo phác đồ của Bệnh viện Phổi Trung ương.

và cơ chế bệnh sinh của bệnh hiện chưa được biết rõ ràng. Bệnh biểu hiện từng đợt với triệu chứng lâm sàng đa dạng do đó dễ bị chẩn đoán 
sai ở giai đoạn sớm.

Triệu chứng lâm sàng thường gặp là viêm vành tai (có thể tới $90 \%$ bệnh nhân), sụn mũi, các đợt viêm cấp tính có xu hướng tự khỏi sau vài ngày hoặc vài tuần, viêm lặp đi lặp lại làm sụn tổn thương nghiêm trọng, bị thay thế bởi mô liên kết sợi. Tổn thương có thể dẫn tới biến dạng vành tai giống hình súp lơ, sống mũi phẳng hình "yên ngựa" điển hình. Mất thính lực, có thể điếc dẫn truyền hoặc điếc tiếp nhận gặp ở $46 \%$ bệnh nhân mắc $R P$, rối loạn chức năng tiền đình đã được ghi nhận trong $6 \%$ bệnh nhân. Triệu chứng hô hấp là yếu tố tiên lượng xấu, viêm thanh quản, khí quản, dẫn đến nhuyễn thanh quản hoặc hẹp vĩnh viễn phải mở khí quản. Tổn thương viêm khí phế quản có thể gây hẹp đường thở khu trú hoặc lan tỏa với biểu hiện đa dạng và dẫn tới dễ nhiễm trùng hô hấp thứ phát. ${ }^{2,10}$

Biểu hiện khớp thường gặp viêm đa khớp hoặc viêm vài khớp không đối xứng, từng đợt cấp tính ở khớp cổ bàn tay, khớp đốt ngón gần, khớp gối thông thường, không có bào mòn cũng như biến dạng khớp. Biểu hiện khác có thể gặp ở tim mạch, ngoài da, thận, thần kinh.

Cận lâm sàng có tăng các dấu ấn viêm như máu lắng, protein phản ứng $\mathrm{C}(\mathrm{CRP})$, kháng thể kháng nhân dương tính từ 22 tới $66 \%$ trường hợp. ${ }^{11}$ Kháng thể kháng collagen typ II, kháng thể ANCA dương tính không đặc hiệu. Sinh thiết sụn vành tai khi cần chẩn đoán ở trường hợp không điển hình.

Chẩn đoán theo tiêu chuẩn của McAdam (1976) khi có từ 3 yếu tố trở lên: viêm sụn tai đối xứng, viêm khớp không bào mòn huyết thanh âm tính, viêm mắt (viêm kết mạc, viêm màng bồ đào, viêm mống mắt, viêm thượng củng mạc, viêm củng mạc), viêm sụn đường hô hấp, rối loạn chức năng tiền đình ốc tai (điếc tiếp nhận, ù tai, chóng mặt), giải phẫu bệnh tổn thương mô sụn. ${ }^{2}$
Hai bệnh nhân chúng tôi đều bắt đầu biểu hiện với triệu chứng viêm sụn vành tai và sụn mũi nhưng chưa được chẩn đoán do bệnh lý viêm đa sụn tái diễn hiếm gặp, triệu chứng biểu hiện không điển hình. Bệnh nhân đầu tiên khi có triệu chứng tới khám bác sỹ chuyên khoa tai mũi họng và chưa được làm chẩn đoán và điều trị đầy đủ, dẫn đến các đợt viêm tái đi tái lại và bệnh nhân xuất hiện thêm triệu chứng viêm sụn tại các cơ quan khác như mắt, sụn sườn, viêm bao gan. Bệnh nhân thứ hai bệnh diễn biến trong thời gian dài, kèm theo đó là tình trạng lao hạch. Khi bệnh nhân xuất hiện tổn thương sụn đường hô hấp gây chít hẹp đường thở, thì được chẩn đoán hướng tới tổn thương do lao, bỏ qua các triệu chứng tổn thương sụn vành tai, sụn mũi, viêm khớp. Bệnh nhân tiếp tục được điều trị thuốc chống lao và phải mở khí quản do hẹp đường thở nặng (đoạn hẹp nhất từ 1-2mm). Tại thời điểm nhập viện cả hai bệnh nhân đều đã diễn biến kéo dài, có đủ tiêu chuẩn chẩn đoán theo McAdam. Do vậy, các bác sỹ lâm sàng cần lưu ý các tổn thương viêm tại sụn vành tai, sụn mũi, và hướng tới chẩn đoán viêm đa sụn tái diễn từ đó mới có thể điều trị sớm, tránh để lại di chứng cho bệnh nhân.

Điều trị viêm đa sụn tái diễn với thể không có tổn thương tạng bao gồm thuốc chống viêm không steroid hoặc corticoid liều thấp, có thể dùng liều tương đương prednisone $1 \mathrm{mg} / \mathrm{kg} /$ ngày nếu đáp ứng kém. Có thể kết hợp với Dapsone 50-200mg/ngày.

Với thể có tổn thương tạng hoặc tổn thương mắt, cần phối hợp với các thuốc ức chế miễn dịch như methotrexate, azathioprine, cyclophosphamide, chlorambucil, leflunomide, mycophenolate mofetil, cyclosporine. Thuốc sinh học như thuốc ức chế ức chế IL-6, ${ }^{12}$ TNF alpha. ${ }^{13}$ Hiện tại mới có những báo cáo trường hợp bệnh, nghiên cứu nhỏ cho thấy hiệu quả của thuốc sinh học. Các phương pháp điều trị 
khác như IVIG, lọc huyết tương. Can thiệp ngoại khoa: Các tổn thương khí phế quản có thể cần can thiệp nội soi phế quản đặt stent, mở khi quản. Có chỉ định thay van tim hoặc graft động mạch chủ tùy từng trường hợp cụ thể. ${ }^{14}$

Sau khi chẩn đoán xác định, bệnh nhân được điều trị chống viêm, bệnh nhân thứ nhất được điều trị với corticoid ngay từ đầu do mức độ bệnh nặng, bệnh nhân đáp ứng tốt, hết sốt, giảm sưng đau vành tai. Bệnh nhân thứ hai do đang điều trị lao nên chúng tôi thận trọng bắt đầu với thuốc chống viêm không steroid nhưng bệnh nhân không đáp ứng và cũng đáp ứng kém với liều methylprednisolone $40 \mathrm{mg} / \mathrm{ngày}$. Sau khi hội chẩn với các bác sỹ chuyên khoa lao, chúng tôi đã quyết định tăng liều lên 80 $\mathrm{mg} / \mathrm{ngày}$ kết hợp với methotrexate $10 \mathrm{mg} / \mathrm{tuần}$. Kết quả cho thấy đây là lựa chọn hợp lý, bệnh nhân hết sốt, tình trạng viêm khớp cải thiện. Xét nghiệm máu chỉ số viêm giảm.

Tỷ suất tử vong của viêm đa sụn tái diễn là $2,16^{1}$ với các yếu tố tiên lượng nặng là tổn thương thanh khí quản và tổn thương thận. ${ }^{10}$ Đây là bệnh lý có nhiều đợt tái đi tái lại tuy nhiên hiện chưa có thang điểm đánh giá mức độ hoạt động thống nhất. Bệnh nhân cần được tái khám định kỳ theo dõi tình trạng lâm sàng và tìm thêm tổn thương cơ quan như siêu âm tim, đo chức năng thông khí hàng năm ${ }^{15}$ và $\mathrm{CT}$ khí quản, nội soi phế quản nếu có tổn thương đường thở. ${ }^{7}$

\section{KÉT LUẬN}

Viêm đa sụn tái diễn là một bệnh hiếm với đặc điểm tổn thương đa cơ quan, triệu chứng lâm sàng phong phú nên có thể gặp ở tất cả các phòng khám chuyên khoa khác nhau. Việc chẩn đoán đúng đóng vai trò quan trọng trong điều trị và dự phòng các biến chứng không thể hồi phục. Bệnh được chẩn đoán bằng các tiêu chuẩn lâm sàng, có hay không kèm theo giải phẫu bệnh và theo dõi đáp ứng với trị liệu corticoid. Tổn thương từng vị trí không đặc hiệu cho chẩn đoán, nhưng khi có thương tổn nhiều cơ quan, đặc biệt các vị trí có sụn giàu proteoglycan cần hướng đến chẩn đoán viêm đa sụn tái diễn. Lựa chọn điều trị theo mức độ bệnh: nhẹ, trung bình (thuốc chống viêm không steroid, corticoid, dapsone), nặng (corticoid kết hợp thuốc ức chế miễn dịch hoặc thuốc sinh học).

\section{TÀI LIẸU THAM KHẢO}

1. Hazra N, Dregan A, Charlton J, Gulliford MC, D'Cruz DP. Incidence and mortality of relapsing polychondritis in the UK: a populationbased cohort study. Rheumatology. Published online July 17, 2015:kev240. doi:10.1093/ rheumatology/kev240.

2. Ritter S. Relapsing Polychondritis. In: Rheumatology. 2019. Vol 2. 7th ed. Elsevier; :1480.

3. Trentham DE. Relapsing Polychondritis. Ann Intern Med. 1998;129(2):114. doi:10.7326/0003-4819-129-2-19980715000011.

4. R. Jaksch-Wartenhorst. Polychondropathia. Intern Med. 1923;6:93-100.

5. Estes SA. Relapsing polychondritis. A case report and literature review. Cutis. 1983;32(5):471-474, 476.

6. Pol K, Jarosz M. Relapsing polychondritis: case report and literature review. Pol Arch Intern Med. 2009;119(10):680-683. doi:10.20452/ pamw.805.

7. Ernst A, Rafeq S, Boiselle $P$, et al. Relapsing Polychondritis and Airway Involvement. Chest. 2009;135(4):1024-1030. doi:10.1378/chest.08-1180.

8. Ben Salah R, Cherif $Y$, Frikha $F$, et al. A Relapsing Polychondritis and Malignancies: A Case Report and Review of 
Literature. J Dermatol Res Ther. 2016;2(6). doi:10.23937/2469-5750/1510041.

9. Lê Thượng Vũ. Trường hợp viêm đa sụn tái tiễn đầu tiên ở Việt Nam. Tạp chí $Y H o ̣ c$ Thành Phố Hồ Chí Minh. 2004;8:140-145.

10. Borgia F, Giuffrida R, Guarneri F, Cannavò S. Relapsing Polychondritis: An Updated Review. Biomedicines. 2018;6(3):84. doi:10.3390/biomedicines6030084.

11. Piette J-C, El-Rassi R, Amoura Z. Antinuclear antibodies in relapsing polychondritis. Ann Rheum Dis. 1999; 58(10):656-657. doi:10.1136/ard.58.10.656.

12. Wendling D, Godfrin-Valnet M, Prati C. Treatment of Relapsing Polychondritis with
Tocilizumab. J Rheumatol. 2013;40(7):1232.11232. doi:10.3899/jrheum.130371.

13. Cazabon S, Over K, Butcher J. The successful use of infliximab in resistant relapsing polychondritis and associated scleritis. Eye. 2005;19(2):222-224. doi:10.1038/ sj.eye.6701457.

14. Emmungil $H$, Aydin SZ. Relapsing polychondritis. Eur J Rheumatol. 2015;2(4):155159. doi:10.5152/eurjrheum.2015.0036.

15. Mathew SD, Battafarano DF, Morris MJ. Relapsing polychondritis in the Department of Defense population and review of the literature. Semin Arthritis Rheum. 2012;42(1):70-83. doi:10.1016/j.semarthrit.2011.12.007

\section{Summary}

\section{RELAPSING POLYCHONDRITIS: A TWO-CASE REPORT}

Relapsing Polychondritis - RP is an autoimmune disease that damages cartilaginous tissues and organs, and leads to complications if not diagnosed and treated. However, this is a rare disease; onset symptoms can be unspecific and make it difficult for an early diagnosis. The objective of the study was to report two relapsing polychondritis cases, describe diagnostic characteristics for early diagnosis and treatment. A descriptive study design was applied in two patients with relapsing polychondritis admitted to Hanoi Medical University Hospital. Both patients had onset symptoms as auricles and nose inflammation and were not diagnosed before admission. Other symptoms included fever, arthritis and patients were admitted to the hospital. They were diagnosed based on McAdam 1976 criteria and had good treatment responses. In conclusion, early diagnosis and treatment in relapsing polychondritis with anti-inflammatory and immunosuppressant medicine is important to prevent complications.

Keywords: Autoimmune diseases, relapsing polychondritis. 